\title{
EFFECTS OF "NEWLY MODIFIED PANCHAGAVYA" ON GROWTH, YIELD AND PEST INCIDENCE OF Capsicum annuum IN OPEN FIELD CULTIVATION
}

\author{
Vidanapathirana N.P. ${ }^{1 *}$, Viduranga R.M.H. ${ }^{1}$, Somachandra K.P. ${ }^{2}$ and Ketipearachchi K.G. ${ }^{1}$ \\ ${ }^{1}$ University of Colombo Institute for Agro-Technology and Rural Sciences, Weligatta New town, Hambantota, Sri Lanka \\ ${ }^{2}$ Regional Agricultural Research and Development Center, Kahagolla, Bandarawela, Sri Lanka \\ *Corresponding Author: nisansala@ uciars.cmb.ac.lk (https://orcid.org/0000-0003-1187-5681) \\ Received: 15.08.2021; Accepted: 13.10.2021; Published: 05.11.2021
}

\begin{abstract}
The Panchagavya is an organic product derived from five products obtaining from cow and it can be modified by adding dry yeast to accelerate the fermentation process. The study was aimed to evaluate the effect of 'Newly Modified Panchgavya' (NMP) on growth, yield and pest incidence of Capsicum annum (variety-Muria 358 F1) in an open field condition. This experiment was carried out using Randomized complete block design (RCBD) with three replicates each contain 25 plants in open field in Bandarawela. The water (control), 3\% NMP, 5\% NMP and neem seed kernel extract were applied as treatments and data collected at weekly intervals. According to the study, NMP contains $2.76 \% \mathrm{~N}, 0.25 \% \mathrm{P}, 2.41 \% \mathrm{~K}, 0.22 \% \mathrm{Mg}, 0.0027 \% \mathrm{Fe}$ and $0.003 \% \mathrm{ppm} \mathrm{Cu}$. The application of $5 \%$ NMP showed significant $(P<0.05)$ increment in number of leaves per plant from three weeks to eight weeks after planting. There was a significant $(P<0.05)$ increment in plant height and yield compared to the control in plants treated with 5\% NMP. The number of pest damaged leaves compared to the total numbers of leaves was lower in plants treated with 5\% NMP. Thus, the study revealed that 5\% NMP is applicable as an organic product to increase growth and yield while reducing pest damage for C. annum.
\end{abstract}

Keywords: Capsicum annuum, Growth, Modified, Neem Seed Kernel Extract, Panchagavya

\section{INTRODUCTION}

Vegetable cultivation is one of the main income sources of Up-country farmers and the area is very popular for exotic vegetables. Capsicum (Capsicum аппиит) can be considered as a popular vegetable grown because it always fetches high market price (Weerakkody and Mawalagedera., 2020). Muria $358 \mathrm{~F} 1$ is a recently introduced exotic variety which popularized within short time. One of the main problems associated with capsicum cultivation, irrespective to varieties, is heavy use of agro-chemicals for pest/disease control and application of large quantities of synthetic fertilizers to get high yield (Hasan et al., 2019; Latifah et al., 2019). The overuse of chemical fertilizer and pesticides in vegetable cultivation make detrimental impact on human health and environment (Savci., 2012). Organic agriculture or cultivating crops without synthetic inputs is one of the popular ways to produce healthy foods under low environmental impact (Scialabba, and Hattam., 2002). There are many natural preparations used in organic agriculture which provide nutrients to plant and protect them from problematic pests and diseases. 'Panchagavya' is a popular organic fertilizer prepared by organic farmers in Tamil Nadu (Rakesh et al., 2017). They used five products obtained from cow to prepare the nutrient mixture as cow dung, cow urine, milk, curd and ghee (Ram., 2017). The organic growers in Tamil Nadu widely use Panchagavya for agricultural and horticultural crops (Sinha., 2014). Panchagavya contains several macro and micronutrients which are required for the growth and development of plants. It contains nutrients, various vitamins, growth regulators, and beneficial micro-organisms (Ram., 2017). It has the potential to promote growth and provide the resistance against pest and diseases (Raghavendra et al., 2014). Since the lactic acid forming bacteria Lactobacillus is present in Panchagavya, $\mathrm{pH}$ is low due to fermentation and the preparation is effective in killing the plant pathogens (Manthivanan et al., 2006). Past studies have shown that there is a positive effect of panchagavya on plant growth and pest/disease management (Pramod et al., 2018). This study attempted to use it as an alternative nutrient source and pesticide in cultivating Capsicum variety Muria 358 F1. Here, the ordinary Panchagavya preparation used in India was slightly modified by adding dry yeast as a fermenting agent and nutrient source which accelerates the fermentation process. Therefore, this study was designed to study the effects of "Newly Modified Panchagavya" on 
growth, yield and pest incidence of Capsicum annиum in an open field cultivation.

\section{METHODOLOGY}

\section{Location and Experimental Design}

This experiment was conducted in the open field in Banadarawela $\left(\mathrm{IU}_{3}\right)$, with maximum and minimum temperature that are ranged between $19-29^{\circ} \mathrm{C}$ and $8-19^{\circ} \mathrm{C}$ respectively and with an average annual precipitation of $1729 \mathrm{~mm}$. Randomized Complete Block Design (RCBD) was used with three replicates and each replicate contained 25 plants.

\section{Seed sowing and Nursery management}

C. annum (variety: Muria 358 F1) seeds were sown in the nursery trays containing sterilized mixture of top soil: partially burned paddy husk at the rate of $1: 1$ as the nursery media. Prepared nursery trays were kept in the polytunnel and practiced daily watering.

\section{Pot preparation and Transplanting}

Poly bags (30 cm x $35 \mathrm{~cm}$, Gauge 300) were filled using the mixture of top soil: compost: partially burned paddy husk at the rate of $3: 2: 1$. The compost used for the study was bought from a private seller. Planting pots were arranged in $40 \mathrm{~cm}$ * $40 \mathrm{~cm}$ spacing in an open field. Potting media was sterilized using $2 \mathrm{~g} / \mathrm{L}$ captan solution. Basal inorganic fertilizer mixture was applied to planting pots according to the Department of Agriculture. The seedlings were transplanted in the polybags.

\section{Preparation of NMP}

Cow dung (1 kg) and cow ghee (142 g) were added into a wide mouthed plastic barrel and stirred using a wooden stick. After, covered using an insectproof net and it was kept in shade for 3 days. Then, cow urine (1 1 l) and water (ll 1 l) were added and mixed properly. It was kept in shade for 15 days after covering it. The prepared mixture was stirred daily to facilitate fermentation. After another 15 days, milk (430 ml), curd ( $285 \mathrm{ml})$, young coconut water $(200 \mathrm{ml})$, two ripen bananas and yeast $(10 \mathrm{~g})$ were added, kept in shade and practiced daily stirring. Prepared mixture was strained after 15 days. Finally, NMP Mixture was stored in a plastic bottle. Nutrient status, pH and EC of Newly Modified Panchagavya were analyzed at the soil and plant laboratory of Tea Research Institute (TRI), Thalawakale.

\section{Preparation of Neem Seed Kernel Extract}

Well dried neem seeds $(1 \mathrm{~kg})$ were ground to make fine powder. The water $(2 \mathrm{~L})$ were added and kept for overnight after closed. Then, the mixture was strained.

\section{Application of Treatments}

Following four treatments were used for the experiment with three replicates. Each replicate consisted of 25 plants.

T1 - Water

T2 - NMP 3\% solution

T3 - NMP 5\% solution

T4 - Neem Seed Kernel Extract

The application concentration of newly modified panchagavya as $3 \%, 5 \%$ was decided based on the pre-trials. The $2.5 \mathrm{~L}$ of any treatment were applied for 25 plants as foliar application in first month after planting. Then, the application amount was increased up to $5 \mathrm{~L}$ from two months after planting.

\section{Management practices}

All management practices were done according to the recommendation of Department of Agriculture.

\section{Data collection}

The total number of leaves and the number of leaves damaged by pest such as trips, aphids, mites and white flies were counted. Number of leaves and numbers of pest damaged leaves per plant was counted and recorded manually. Data collection was done once a week starting from 2 WAP to 8WAP. Plant height was measured weekly starting from one WAP and recorded. Yield was measured using electronic scale and recorded.

\section{Data analysis}

The data were statistically analyzed using the Analysis of Variance (ANOVA) to detect the significance at the treatment level. The difference between treatments was compared by the Tukey test at $95 \%$ confidence using Minitab17.

\section{RESULTS AND DISCUSSION}

\section{Nutrient composition of NMP}

According to the analysis of NMP in the soil and plant laboratory of Tea Research Institute (TRI), Thalawakale, NMP comprises $2.76 \% \mathrm{~N}, 0.25 \% \mathrm{P}$, $2.41 \% \mathrm{~K}, 0.22 \% \mathrm{Mg}, 0.0027 \% \mathrm{Fe}$ and $0.003 \% \mathrm{ppm}$ $\mathrm{Cu}$. A past research on panchagvaya has shown that, it contained $1000 \mathrm{ppm}$ total nitrogen, 175. 40 ppm total phosphorous, 194. $10 \mathrm{ppm}$ total potassium, $1.27 \mathrm{ppm}$ total zinc, $0.38 \mathrm{ppm}$ total 
copper, $29.71 \mathrm{ppm}$ total iron and magnesium (Rawat et al., 2020). The effect of different treatments on growth, yield and pest damage were given below (Table 1)

Table 1: Effects of different treatments on number of leaves, Number of damage leaves, Plant height and Yield

\begin{tabular}{|c|c|c|c|c|c|c|c|c|c|}
\hline Parameter & Treatment & 1 WAP & $2 \mathrm{WAP}$ & 3 WAP & 4 WAP & 5 WAP & 6 WAP & 7 WAP & 8 WAP \\
\hline \multirow{5}{*}{ NOL } & Water & $4.30^{\mathrm{a}}$ & $9.50^{\mathrm{a}}$ & $13.40^{\mathrm{c}}$ & $17.70^{\mathrm{c}}$ & $22.20^{\mathrm{c}}$ & $25.70^{c}$ & $29.60^{c}$ & $34.20^{c}$ \\
\hline & $3 \% \mathrm{NMP}$ & $4.30^{\mathrm{a}}$ & $10.26^{\mathrm{a}}$ & $17.50^{\mathrm{b}}$ & $25.00^{\mathrm{b}}$ & $33.10^{\mathrm{b}}$ & $44.00^{\mathrm{b}}$ & $55.40^{\mathrm{b}}$ & $68.40^{\mathrm{b}}$ \\
\hline & $5 \%$ NMP & $4.46^{\mathrm{a}}$ & $10.40^{\mathrm{a}}$ & $22.00^{\mathrm{a}}$ & $33.10^{\mathrm{a}}$ & $45.70^{\mathrm{a}}$ & $60.23^{\mathrm{a}}$ & $76.70^{\mathrm{a}}$ & $95.60^{\mathrm{a}}$ \\
\hline & NSKE & $4.50^{\mathrm{a}}$ & $10.20^{\mathrm{a}}$ & $16.9^{\mathrm{bc}}$ & $22.70^{\mathrm{bc}}$ & $29.30^{\mathrm{bc}}$ & $35.40^{\mathrm{bc}}$ & $41.60^{\mathrm{bc}}$ & $48.10^{\mathrm{bc}}$ \\
\hline & $\mathrm{P}$ & 0.407 & 0.091 & 0.001 & 0.001 & 0.000 & 0.000 & 0.000 & 0.000 \\
\hline \multirow{5}{*}{ NDL } & Water & - & $2.40^{\mathrm{a}}$ & $11.20^{\mathrm{a}}$ & $15.60^{\mathrm{a}}$ & $20.40^{\mathrm{a}}$ & $24.40^{\mathrm{a}}$ & $28.50^{\mathrm{b}}$ & $33.00^{c}$ \\
\hline & $3 \% \mathrm{NMP}$ & - & $2.34^{\mathrm{a}}$ & $9.00^{\mathrm{a}}$ & $13.90^{\mathrm{a}}$ & $22.10^{\mathrm{a}}$ & $31.30^{\mathrm{a}}$ & $41.46^{\mathrm{a}}$ & $53.50^{\mathrm{a}}$ \\
\hline & $5 \% \mathrm{NMP}$ & - & $2.54^{\mathrm{a}}$ & $10.10^{\mathrm{a}}$ & $17.50^{\mathrm{a}}$ & $26.60^{\mathrm{a}}$ & $32.30^{\mathrm{a}}$ & $37.60^{\mathrm{ab}}$ & $43.20^{\mathrm{b}}$ \\
\hline & NSKE & - & $2.30^{\mathrm{a}}$ & $11.40^{\mathrm{a}}$ & $18.50^{\mathrm{a}}$ & $25.30^{\mathrm{a}}$ & $31.30^{\mathrm{a}}$ & $38.60^{\mathrm{ab}}$ & $45.33^{b}$ \\
\hline & $\mathrm{P}$ & - & 0.498 & 0.427 & 0.232 & 0.419 & 0.226 & 0.048 & 0.000 \\
\hline \multirow{5}{*}{ PH } & Water & $6.36^{\mathrm{a}}$ & $9.96^{\mathrm{a}}$ & $11.24^{\mathrm{b}}$ & $12.63^{\mathrm{b}}$ & $14.04^{\mathrm{b}}$ & $15.46^{\mathrm{b}}$ & $16.73^{\mathrm{b}}$ & $18.01^{\mathrm{b}}$ \\
\hline & $3 \%$ NMP & $6.15^{\mathrm{a}}$ & $10.72^{\mathrm{a}}$ & $14.03^{\mathrm{ab}}$ & $17.21^{\mathrm{a}}$ & $20.57^{\mathrm{a}}$ & $23.91^{\mathrm{a}}$ & $27.07^{\mathrm{a}}$ & $30.37^{\mathrm{a}}$ \\
\hline & $5 \% \mathrm{NMP}$ & $6.21^{\mathrm{a}}$ & $10.78^{\mathrm{a}}$ & $14.96^{\mathrm{a}}$ & $18.77^{\mathrm{a}}$ & $22.61^{\mathrm{a}}$ & $26.19^{\mathrm{a}}$ & $30.01^{\mathrm{a}}$ & $33.56^{\mathrm{a}}$ \\
\hline & NSKE & $6.40^{\mathrm{a}}$ & $10.61^{\mathrm{a}}$ & $13.28^{\mathrm{ab}}$ & $15.89^{\mathrm{ab}}$ & $18.44^{\mathrm{ab}}$ & $21.00^{\mathrm{ab}}$ & $23.72^{\mathrm{ab}}$ & $26.21^{\mathrm{ab}}$ \\
\hline & $\mathrm{P}$ & 0.395 & 0.681 & 0.018 & 0.004 & 0.004 & 0.003 & 0.0003 & 0.004 \\
\hline \multirow{5}{*}{ Yield } & Water & & & & & $7.20^{\mathrm{b}}$ & $10.09^{\mathrm{b}}$ & $6.70^{\mathrm{b}}$ & $5.80^{\mathrm{b}}$ \\
\hline & $3 \%$ NMP & & & & & $16.20^{\mathrm{b}}$ & $22.40^{\mathrm{ab}}$ & $24.80^{\mathrm{a}}$ & $15.80^{\mathrm{ab}}$ \\
\hline & $5 \%$ NMP & & & & & $36.90^{\mathrm{a}}$ & $38.40^{\mathrm{a}}$ & $36.50^{\mathrm{a}}$ & $14.90^{\mathrm{ab}}$ \\
\hline & NSKE & & & & & $22.90^{\mathrm{ab}}$ & $21.80^{\mathrm{ab}}$ & $22.40^{\mathrm{ab}}$ & $24.70^{\mathrm{a}}$ \\
\hline & $\mathrm{P}$ & & & & & 0.008 & 0.023 & 0.006 & 0.034 \\
\hline
\end{tabular}

Means followed by the same superscripts are not significantly different $(P<0.05)$ according to Tukeys test, WAP - Weeks After Planting; NMP -Newly Modified Panchagawya; NSKE - Neem Seed Kernel Extract; NOL-number of leaves; NDLNumber of damage leaves; PH-Plant height; Y-yield

\section{Effects of different treatments on the total number of leaves}

The highest number of leaves per plant was recorded with 5\% NMP (T3) followed by $3 \%$ NMP (T2) in this experiment (Table 1). There was no significant difference $(\mathrm{P}>0.05)$ among treatments on the number of leaves of Capsicum annum plants in 1 and 2 WAP. There were significant differences $(\mathrm{P}<0.05)$ among treatments in 3 WAP to 8 WAP. T3 (5\% NMP) had a higher performance on number of leaves of plants than other treatments. This may be due to the micro and macro nutrients and plant growth hormones present in NMP. The panchagavya contains macro and micronutrients such as nitrogen, potassium, sodium. molybdenum, magnesium, iron and phytohormone such as auxins, cytokinin, gibberellin (Uthirapandi et al., 2018). Ashwagandha plant sprayed with panchagavya, produced higher number of leaves per plant (Mohanlakshmi et al., 2008). The total number of leaves and nodules of panchagavya applied Sounthern sunnhemp plants increased than the control plants (Vallimayil and Sekar., 2012).

\section{Effect of different treatments on number of pest damaged leaves}

There was no significant difference on leaves damaged by pest such as trips, aphids, mites and white flies of this experiment in 2 WAP to 6 WAP (Table 1). There was a significant difference among treatments on 7 WAP and 8 WAP. Although, the lowest number of damaged leaves recorded from T1 (33) at $8^{\text {th }}$ week, the highest pest damaged was recorded from $\mathrm{T} 1$ considering the total number of leaves presence at $8^{\text {th }}$ week. When comparing T3 (5\% NMP) with the no. of leaves at $8^{\text {th }}$ week, it showed better results on pest control. The past studies showed, the panchgavya increased the immunity of plants and gave resistance against the pest and diseases (Raghavendra et al., 2014). The application of panchagavya reduced the shoot and fruit borer (Earias vittella) population in vitro condition (Pazhanisamy and Archunan., 2019)

\section{Effect of different treatments on number of plant height}

Plant height was not significantly differed at 1 WAP and 2 WAP in this experiment. After 3 WAP 
to $8 \mathrm{WAP}$ there was a significant difference among treatments. The highest plant height was recorded as $33.565 \mathrm{~cm}$ in T3 (5\% NMP) followed by T2 (3\% NMP). It showed that NMP can accelerate the growth of plants. The application of panchagavya recorded higher plant height which facilitates rapid cell division and multiplication due to the growth enzymes present in it might be the possible reason for the high growth characters (Sanjutha et al., 2008). The application of panchagavya increases the plant height, number of fruits, number of branches and weight of single fruit of Solanum melongena (Swarnam et al., 2016).

\section{Effects of different treatments on plant yield}

According to this experiment, there were significant differences among treatments (Table 1). The highest yield found that plants treated with 5\% NMP (T3) and the lowest yield found from T1 (water) in 5WAP to 7 WAP. This might be due to the nutrition, growth promoting hormones and pest controlling ability included in NMP. Past researchers investigated that the influence of liquid organic manures such as Panchagavya, Jeevamruth, and Beejamruth on the growth, nutrient content and yield of tomato and found that the panchagavya is an efficient plant growth stimulant that enhances the biological efficiency of crops (Gore and Sreenivasa., 2011). It is used to activate biological reactions in the soil and to protect the plants from disease incidence.

\section{CONCLUSIONS}

Results revealed that Newly Modified Panchagawya at 5\% concentration increased plant growth and reduced pest damage. Neem Seed Kernel Extract (NSKE) has a proven efficacy as a pesticide and the present study showed NMP is equally performed as NSKE against pests. Therefore, it can be concluded that NMP is a good alternative nutrient source and a pesticide which can replace certain amount of synthetic chemicals in agriculture.

\section{REFERENCES}

Gore, N.S. and Sreenivasa, M.N. 2011. Influence of liquid organic manures on growth, nutrient content and yield of tomato (Lycopersicon esculentum Mill.) in the sterilized soil. Karnataka Journal of Agricultural Sciences, 24(2), pp 153-157

Hasan, M., Robbani, M., Parvin, R., Mehedi, M.N.H. and Hossain, I. 2019. Effect of NPK on growth, yield and seed quality of hybrid Chilli. International Journal of Agricultural
Research, Innovation and Technology,9(1), pp.35-41.

Latifah, E., Dewi, H.A., Daroini, P.B., Korlina, E., Hasyim, A., Andri, K.B., Zakariya, A.Z., Kuntariningsih, A., Negoro, A.A., Hakim, A.L. and Luther, G.C. 2019, February. Impact of starter solution technology on the use of fertilizers in production of chilli (Capsicum frutescens L.). In IOP Conference Series: Earth and Environmental Science, 230 (1), pp. 012063). IOP Publishing.

Manthivanan R., Edvin S.C., Viswanadan, k, and Chandrasekaran, D. 2006. Chemical microbial composition and anti bacterial activity of modified panchagavya. International Journal of Cow Science, 2(2), pp 23-26

Mohanlakshmi, M., and Vadivel, E. 2008. Influence of organic manure and bio-regulators on growth and yield of Ashwagandha. International Journal of Agricultural Sciences 2: pp 429-432

Pazhanisamy, M. and Archunan, K. 2019. Efficacy of botanicals extracts mixture with panchagavya against shoot and fruit borer, Earias vittella (Fab.) on bhendi under in vitro condition. Journal of Biopesticides, 12(1), pp.36-39.

Pramod Kumar, Naushad Khan, Prashant Deo Singh, Anand Singh, Yogesh, Vikas Yadav. 2018. Panchagavya: A low cost organic input in organic farming-a review. International Journal of Chemical Studies, 6(6), pp 575-577

Raghavendra, K.V., Gowthami, R., Shashank, R. and Harish Kumar, S. 2014. Panchagavya in organic crop production. Pop Kheti, 2(2), pp.233-236.

Rakesh, S., Poonguzhali, S., Saranya, B., Suguna, S. and Jothibasu, K. 2017. Effect of Panchagavya on growth and yield of abelmoschus esculentus cv. Arka Anamika. International Journal of Current Microbiology and Applied Sciences, 6(9), pp 3090-3097.

Ram, A.A.M. 2017. Panchagavya is a bio-fertilizer in organic farming. International Journal of Advance Science and Research, 2(5), pp.54-57.

Rawat, N.S., Lathwal, S.S., Panchbhai, G.J., Pal, R.K., Jha, A.K. and Jamra, M.S. 2020. Physical, microbial and biochemical composition of biopesticides based on cow urine and dung with medicinal plants, Journal of Pharmacognosy and Phytochemistry, 9(5), pp 754-758

Sanjutha, S., Subramanian, S., Rani, C.I. and Maheswari, J. 2008. Integrated nutrient management in Andrographis paniculata. Research Journal of of Agriculture and Biological Science, 4(2), pp.141-145.

Savci, S. 2012. Investigation of effect of chemical fertilizers on environment. Apcbee Procedia, 1, pp.287-292. 
Scialabba, N. and Hattam, C. eds. 2002. Organic agriculture, environment and food security (No. 4). Food \& Agriculture Organization, pp 5-6

Sinha, K. 2014. Panchagavya: Low Cost Organic Input for Agricultural and Horticultural Crops., 2(4), pp 47-49.

Swarnam, T., Velmurugan, A. and Roy, N. 2016. Effect of Foliar Application of Panchagavya on Yield and Quality Characteristics of Eggplant (Solanum melongena L). Advances in life sciences. 5(7), pp 2636-2639.

Uthirapandi, V., Suriya, S., Boomibalagan, P., Eswaran, S., Ramya, S.S., Vijayanand, N. and Kathiresan, D. 2018. Organic Fertilizing Effect of Panchagavya on Growth and Biochemical Parameters of Holy Basil (Ocimum sanctum L.). International Journal of Current Microbiology and Applied Sciences, 7(6), pp.2637-2644.

Vallimayil, J. and Sekar, R. 2012. Investigation on the effect of panchagavya on sounthern sunnhemp mosaic virus (SSMV) infected plant systems. Global Journal of Environmental Research, 6(2), pp.75-79.

Weerakkody, W.A.P. and Mawalagedera, S.M.M.R. 2020. Recent developments in vegetable production technologies in Sri Lanka. In Agricultural Research for Sustainable Food Systems in Sri Lanka, pp. 189-214. Springer, Singapore. 